\title{
Status of Women in Ancient Greece
}

\author{
Zhulduz Amangelidyevna Seitkasimova \\ M. Auezov South Kazakhstan State University, KAZAKHSTAN \\ Faculty of Pedagogy and Culture, Shymkent
}

Received 18 October 2019 • Revised 12 December 2019 • Accepted 21 December 2019

\begin{abstract}
This paper examines the status, position and roles of women in ancient Greece. Based on available historical sources, it can be clearly established that women in ancient Greece had an inferior position to men. They were primarily viewed as "species-extending beings". In none of the Greek city-states did women have political rights and were not considered as citizens. The status of women in ancient Greece, in terms of role, position, opportunity etc., varied from one city-state to another. This status is well known for ancient Athens, based on the large number of historical sources that can document the basic characteristics of the status of women in ancient Athens.
\end{abstract}

Keywords: women' status, ancient Greece, society, family, gender discrimination.

\section{Introduction}

What was the status and positions of women in ancient Greece, and what was the main characteristics of that status? Women in the ancient Greek world had no possess all rights as men possessed and had few rights in comparison to male citizens. The key restrictions that women had was that they could not vote in different public affairs, and also could not own or inherit land. It was considered in society that a woman's place should be in the home and her crucial role and purpose in the home, as well as purpose in life should be the rearing of children, to care and educate them, in accordance to accepted societal system of values. Cartwright (2016) especially emphasized the fact that it is a general description, and when considering the role of women in ancient Greece it should remembered that information regarding specific city-states is often lacking, is almost always generated from male authors, as well as that only in Athens can their status and role be described in any great detail. Moreover, the author considers that "Neither are we sure of the practical and everyday application of the rules and laws that have survived from antiquity" (Ibid.). Also, it is known from historical sources that Spartan women were in some specific positions and treated somewhat differently than the women in other city-states. The Spartan women had regularly included in some aspects of military education, for example, they had to do physical training like men, in order to be ready together with the men to protect homeland. There were some more different specifics, such as the women in Sparta were permitted to own land, and could drink wine. These specifics are very significant, due to the fact that there was no democracy in Sparta, that kind of democracy that was exercised in ancient Athens and its colonized city-states.

(C) Authors. Terms and conditions of Creative Commons Attribution 4.0 International (CC BY 4.0) apply. Correspondence: Zhulduz Amangelidyevna Seitkasimova (PhD student), M. Auezov South Kazakhstan State University, Faculty of Pedagogy and Culture, Shymkent, KAZAKHSTAN. E-mail: zhulduz_asoo1@yahoo.com. 
Cartwright (2016) also mentions that there were also categories of women which are less well-documented than others such as professional women who worked in shops and as prostitutes and courtesans; the social rules and customs applied to them are even more vague than for the female members of citizen families. Finally, in contrast to the lot of most women, some exceptionally and exceptional, rose above the limitations of Greek society and gained lasting acclaim as poets (Sappho of Lesbos), philosophers (Arete of Cyrene), leaders (Gorgo of Sparta and Aspasia of Athens), and physicians (Agnodice of Athens).

\section{Historical and social context of the ancient Greece}

There are no specific or generally accepted dates for the beginning and end of the ancient Greece period. In common usage, this period refers to the whole of Greek history before the founding of the Roman Empire, but historians use the term more precisely. Thus, some authors include periods of Minoan and Mycenaean civilization in this period (from about 1600 BC to about $1100 \mathrm{BC}$ ) (Bagnall et al., 2012), while others dispute this, considering that these civilizations, although from the Greek-speaking area, are quite different from later Greek cultures, so they should be classified separately.

According to tradition, the period of ancient Greece begins with the first Olympic Games in $776 \mathrm{BC}$, but most modern-day historians extend the term to around $1000 \mathrm{BC}$. The traditional end date of the period of ancient Greece is considered to be the death of Alexander the Great in 323 BC, and the period that follows is called the Hellenistic age. These dates have been agreed upon by historians, but there are some authors considering the civilization of ancient Greece to be an uninterrupted period that lasted until the beginning of Christianity in the $3^{\text {rd }}$ century $\mathrm{AD}$.

Ancient Greece is considered by some historians to be the cornerstone of the culture of Western European civilization (McKeown, 2018). Greek culture exerted a strong influence on the Roman Empire, which transmitted its form throughout many parts of Europe (Cartwright, 2014). The civilization of ancient Greece had an immense influence on the language, politics, education, philosophy, art and architecture of the modern world, especially during the Renaissance in Western Europe and again during the flourishing of neoclassicism in $18^{\text {th }}$ and $19^{\text {th }}$ centuries in Europe and in both Americas.

Greek city-states were initially monarchies, although many cities were very small so the name "king" for their rulers could easily be misleading because of the present meaning of the word (Bagnall et al., 2012). Inland, always close to arable land, a small layer of landowners had power. They shaped the warrior aristocracy by fighting often in small interurban wars around the country. However, the rise of the trading class (which came with the introduction of coins around 680 BC) triggers a class conflict in major cities. From 650 BC onwards, aristocracies were

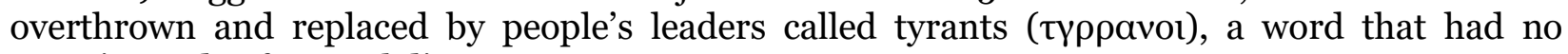
meaning today for cruel dictators.

By the $6^{\text {th }}$ century BC, several dominant cities in Greek sphere emerged. These were the cities of Athens, Sparta, Corinth and Thebes. Each of them put the surrounding rural areas and smaller towns under their control, and Athens and Corinth, in turn, became the main naval and commercial forces.

In Sparta, the aristocracy held power, and the Lycurgus constitution (about 650 DC), which further consolidated its power, gave Sparta a permanent militaristic regime under a dual monarchy. Sparta dominated the other cities on the Peloponnese, forming an alliance with Corinth and Thebes. 
In Athens, on the contrary, the monarchy was banned in $683 \mathrm{BC}$, and Solon's reforms introduced a semi-constitutional composition of aristocratic rule. The aristocrats were replaced by the tyranny of Peisistratos and his sons, who made the city a great naval and commercial force. When the Peisistratides were overthrown, Cleisthenes founded the first world democracy (500 BC) whose power was vested in a council of all male citizens.

The wealth of Athens attracted many talented people from all parts of Greece, then class of a wealthy, unemployed people had created who became patrons of the arts (Boys-Stones et al., 2009). The Athenian state also supported science and art, and especially architecture. Athens became the center of Greek literature, philosophy and art. Some of the greatest names in Western European cultural and intellectual history lived in Athens during this period: the playwrights Aeschylus, Aristophanes, Euripides and Sophocles, the philosophers Socrates, Plato and Aristotle, the historians Herodotus, Thucydides and Xenophon, the poet Simonidus and the sculptor Phidias. The city became, in Pericles' words, a "Hellenic School".

Other Greek states initially accepted the Athenian leadership in the continuation of the war against the Persians, but after the fall of the conservative politician Kimon in $461 \mathrm{BC}$, Athens became a more pronounced imperialist force (Bagnall et al., 2012). After the Greek victory at the Battle of the Eurymedont 466 BC, the Persians were no longer a threat, so some states, such as Naxos, tried to withdraw from the alliance but were forced to obey. The new Athenian leaders, Pericles and Ephialtes, let relations between Athens and Sparta deteriorate, so war broke out in 458 BC. After several years of endless war, a 30-year peace was signed between the Delian and Peloponnesian Alliances (Sparta and its allies).

\section{3. "Status" of women in Greek myths}

Presence of women in Greek myths is clearly more significant then their position in the ancient Greek society, where they obviously had limited role. It is contradictory a little bit. Considering their limited role in actual society of ancient Greece there is a surprisingly strong cast of female characters in Greek religion and mythology (Cartwright, 2006).

Athena was the goddess of wisdom, the weaving, the craft and the more sober side of war (violence and bloodthirsty were the traits of Are). Also, she was patron of the city of Athens. Athena's wisdom follows the technical knowledge required in weaving, metallurgy but also includes the cunning (metis) of characters such as Odysseus. She has a holy owl and an olive tree. The first stories of Athens speak of her as a bird goddess. It was originally conceived as a goddess with wings, and even in some myths it was itself a bird - an owl. That is why it is not surprising why in the myths that arose later, Athena's message came over the eagle, falcon, etc. Athena's best friend is Nike, the goddess of victory. Athens appears as the patron saint of many Greek heroes, including Heracles, Odysseus, and Jason. She is also the favorite daughter of Zeus, born out of his head.

Common to most ancient cultures where agriculture, due to the fact that it was crucial to the community, female fertility goddesses were extremely important and particularly venerated - Demeter and Persephone being the most revered for the Greeks. In Greek mythology, Demeter $(\Delta \eta \mu \eta \dot{\tau} \tau \rho)$ is the daughter of Cronus and Rhea, goddess of grain and fertility, the nurturer of young and green land, guardian of marriage and holy law. In Homeric hymns, she is called the "bringer of the age", which is considered a sign that she was revered long before she became one of the

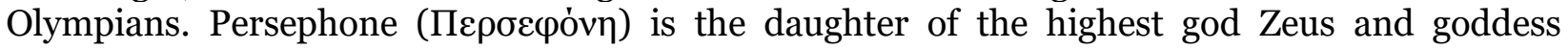
Demeter, the wife of the god of the underworld Hades. In that underworld empire, she held the same position as Hera at Olympus. She was Hades's sovereign over the souls of the dead and the gods of the underworld. Persephone was as relentless and ruthless as Hades himself. She cast the curse of death, and that is why, in mythology, there are four seasons we know. 
As it was the case in other ancient male-dominated literature, women are often cast as troublemakers, from jealous Hera to Aphrodite employing her charms to make men lose their wits (Cartwright, 2016). Myths and literature abound with female characters trying their best to derail the plans of male heroes, from the supreme witch Medea to the deadly, if lovely, Sirens. In Greek myths they can also be represented as ruled only by wild passion and ecstatic emotion such as the Maenads. From the other side, the ideal chaste woman loyal to her absent husband is epitomized by Penelope in Homer's Odyssey.

The Muses are another positive representation, celebrated not only for their physical beauty but also their wide-ranging skills in the arts. The Muses in ancient Greek mythology are nine ancient deities, the daughters of Zeus and Mnemosyne. The god Apollo was their protector. Originally these deities were Nymphs of the Mountain and the Water. Hesiod in Theogony recounts (Reeve, 2006): "Mnemosyne slept in Pieria (Pieria Mountains) with the son of Saturn and gave birth to these virgins who make us forget our sufferings and soothe our pains. Nine nights later, the prudent Zeus climbed into his holy bed, sleeping beside Mnemosyne, away from all the immortals. After a year, when the seasons and months had ended, and when many days passed Memorial gave birth to nine daughters ... all of which were fascinated by music ...”. Their names are: Cleo, Eutterpi, Thalea, Melpomeni, Terpsihori, Erato, Polymnia, Urania, and Kalliopi.

Cartwright (2016) made the question concerning the role of Muses, whether these fictional characters had any bearing on the role of women in real life is an open question, as is the more intriguing one of what did Greek women themselves think of such male-created rolemodels?, and concluded that we perhaps never know it.

\section{Status of women in the family}

In ancient Greece, women were expected to rear children and manage the daily requirements of the household the family home. In fulfilling these home duties, they had the help of slaves if the husband could afford them. A kind of contact with non-family males was discouraged and women largely occupied their time with indoor activities such as wool-work and weaving. Women could go out and visit the homes of friends and were able to participate in public religious ceremonies and festivals. Whether women could attend theatre performances or not is still disputed amongst scholars (Cartwright, 2016). It is obvious that women could not attend public assemblies, vote, or hold public office, and even a woman's name was not to be mentioned in public.

What was the status of married women in ancient Greece? The married women were, at least in the eyes of the law, under the complete authority of their husbands. It can be seen that writers as Aristotle have no doubts that women were intellectually incapable of making important decisions for themselves (McKeown, 2018). From todays' points of view, it represented clear established gender discrimination. In practice, of course, individual couples may well have shared their lives more equitably. Women were expected to be faithful to their husbands, but the reverse was not the case as husbands could freely engage the services of prostitutes, live-in lovers, and courtesans (Cartwright, 2016). It was accepted by the law that any woman who did not preserve the honor of the family, was guilty of the serious crime of moicheia which would lead to her being banned from practicing in public religious ceremonies. A husband who discovered that his wife was engaging in sexual relations with another man could murder the lover without fear of prosecution, and it was in accordance with custom law. This fact about cheating is also proof of clear discrimination in status of men and women in ancient Greece.

Concerning possibilities to inherit property from parents, there we also elements of discrimination between men and women. If a woman's father died, she usually inherited nothing if she had any brothers. If she were a single child, then either her guardian or husband, when 
married, took control of the inheritance. About this issue, Cartwright (2016) writes the following: "In some cases when a single female inherited her father's estate, she was obliged to marry her nearest male relative, typically an uncle. Females could inherit from the death of other male relatives, providing there was no male relative in line. Women did have some personal property, typically acquired as gifts from family members, which was usually in the form of clothes and jewelry. Women could not make a will and, on death, all of their property would go to their husband." It is obvious that there was discriminations in rights of men and women, also in this area of everyday life in ancient Greece.

\section{Position of girls}

The ancient Greek society was clearly man-centered society, in many aspects of societal and family life (McKeown, 2018). As in many other male-dominated and agrarian cultures, female babies were at a much higher risk of being abandoned at birth by their parents than male offspring. "Children of citizens attended schools where the curriculum covered reading, writing, and mathematics. After these basics were mastered, studies turned to literature (for example, Homer), poetry, and music (especially the lyre). Athletics was also an essential element in a young person's education. Girls were educated in a similar manner to boys but with a greater emphasis on dancing, gymnastics, and musical accomplishment which could be shown off in musical competitions and at religious festivals and ceremonies" (Cartwright, 2016). Based on this description of the role of girls' education, it was accepted in society that the ultimate goal of a girl's education was to prepare her for her role in rearing a family and not directly to stimulate intellectual development, or for takes part in the public life.

Cartwright (2016) also claims that an important part of a girl's upbringing involved pederasty (it was not only practised by mature males and boys). This was a relationship between an adult and an adolescent which included sexual relations but in addition to a physical relationship, the older partner acted as a mentor to the youth and educated them through the elder's worldly and practical experience. Pederasty in ancient Greece was a socially acknowledged romantic relationship between an adult male (the erastes) and a younger male (the eromenos) usually in his teens (Reeve, 2006). It was characteristic of the Archaic and Classical periods. The influence of pederasty on Greek culture of these periods was so pervasive that it has been called "the principal cultural model for free relationships between citizens" (Ibid.).

\section{Position of young women}

It was common accepted custom in ancient Greece that young women were expected to marry as a virgin. Moreover, the marriage was usually organized by their father, who chose the husband and accepted from him a dowry. If a woman had no father, then her interests (marriage prospects and property management) were looked after by a guardian (kyrios or kurios), perhaps an uncle or another male relative (Cartwright, 2016). Married at the typical age of 13 or 14, love had little to do with the matching of husband and wife (damar). Of course, love may have developed between the couple, but the best that might be hoped for was philia - a general friendship/love sentiment; eros, the love of desire, was often sought elsewhere by the husband. All women were expected to marry, there was no provision and no role in Greek society for single mature females.

\section{Conclusion}

The general status and position of the women was not equal in all city-states of ancient Greece. Although democratically regulated, Athens did not give women nearly as much rights as 
men possessed. Moreover, their position was far worse than that of the Spartans' women. Athenians had no right to participate in public life or to vote. Women spent most of their time in homes raising children and doing different home everyday activities. Only hetaires were released into the world that provided special pleasures for men. Notwithstanding this attitude, some women, apart from the hethaires, have been able to exercise their right to mean more than "beings for birth" (McKeown, 2018). It is well known that Pythagoras also received women who were equal to men at his school. The Athenian women were married at the age of eighteen. In the event of the death of a spouse, the woman would usually marry his best friend. She had no right to inherit the property of her deceased husband.

This research did not receive any specific grant from funding agencies in the public commercial, or not-for-profit sectors.

The author declares no competing interests.

\section{References}

Bagnall, R. S., Brodersen, K., Champion, C. B., Erskine, A., \& Huebner, S. R. (Eds.) (2012). The encyclopedia of ancient history. Wiley-Blackwell.

Boys-Stones et al. (2009). The Oxford handbook of Hellenic studies. Oxford University Press.

Cartwright, M. (2014). The role of women in the Roman world. Retrieved 10 July 2019, from https://www.ancient.eu/article/659/the-role-of-women-in-the-roman-world/.

Cartwright, M. (2016). Women in ancient Greece. Retrieved 10 July 2019, from https://www.ancient.eu/article/927/women-in-ancient-greece/.

Reeve, C. D. C. (2006). Plato on Love: Lysis, Symposium, Phaedrus, Alcibiades with Selections from Republic and Laws. Hackett Publishing Co.

McKeown, M. (2018). Women through history: Women's experience through the ages. Retrieved 10 July 2019, from https://owlcation.com/humanities/Women-Through-History. 